\title{
Time Management and Students Academic Performance in Higher Institutions, Nigeria - A Case Study of Ekiti State
}

\author{
ADEBAYO, Florence Aduke (PhD) \\ Faculty of Education, Ekiti State University \\ Ado - Ekiti, Ekiti State, Nigeria \\ E-mail: dukesseyi@yahoo.com
}

Received: February 18, 2015

Accepted: March 30, 2015 Published: April 20, 2015

doi:10.5296/ire.v3i2.7126

URL: http://dx.doi.org/10.5296/ire.v3i2.7126

\begin{abstract}
Time management is a set of practices that work together to help you get more value out of your time with the aim of improving the quality of your life. Students most often do not utilize their time judiciously as expected to attain their goals. Hence, this paper examined the impact of time management on students' academic performance in higher institutions Nigeria. Hypotheses were generated to identify the constraints of time management among students. The results revealed that procrastination, prioritization and planning were strong indices that affected the students' academic performance in relation to time management. It was strongly recommended that students have to be conscious of time in performing their academic activities so that the level of their academic performance can be high.

Since procrastination among all the variables has much impact on academic performance according to the findings, students should strive hard to complete their assignments as well as other academic activities on time so as to avoid not meeting deadlines.
\end{abstract}

Keywords: Time management, academic performance, prioritorization, procrastination

\section{Introduction}

Time management is an art and a science. Everybody has to learn how to do it. Some people have a good skill at it but not everybody. Time is a priceless source. Time is the single resources that can't be changed, can't be taken back once it is used and is used completely at the appreciation of the owner. No one can control the moving of time but everyone is able to 
decide how to use it. Time management is self-management with an explicitly focus on time in deciding what to do; on how much time to allocate to the activities; on how activities can be done more efficiently and on when the time is right for particular activities (www.sage-reference.com/organizationalpyschology).

Time management is the art of arranging, organizing, scheduling and budgeting one's time for the purpose of generating more effectiveness work and productivity. It is a priority-based structuring of time allocation and distribution among competing demands since time cannot be stored, and its availability can neither be increased beyond nor decrease from the 24 hours. Gerald(2002) defined time management as a set of principles, practices, skills, tools and systems that work together to help you get more value out of your time with the aim of improving the quality of your life. Argarwal (2008) in his contribution asserts that time management is usually a personal problem and if one instinctively knows what the right is, then there is no need to worry. Daily life is not actually a gamble and allocating time to every activity will help. Unlike other things, time lost never comes back.

Time management is focused on solving problems. Examples of common problems are; being unable to deal with distractions, deadline pressure, and procrastination, and self-discipline, ambiguity of personal goals, not being able to say "no", excessive social relations, indetermination, perfectionism and messy task. Akomolafe (2005) stated that time really cannot be managed because it cannot be slowed down, speed up or manufactured. But Quek (2001) believed that time can be managed because when one wants to solve the problem of procrastination, one needs to learn and develop time management skills. In the mind of the researchers, there is an indication that Quek feels that procrastination may affect time management. Time is natural; however, people live and work or exist within time. Therefore, time rolls along with human existence.

To the researcher however, time management is as important as human and material resources in any organization. From observation, poor time planners seem to be faced with low productivity, inefficiency, ineffectiveness and low morale, stress and frustration with themselves. Time is always available although it waits for no one, and is no respecter of gender as reflected in the research conducted by Omolola (2010) that both male and female undergraduate are affected by time management.

Academic performance is the outcome of education, that is, the extent to which a student, teacher or institution has achieved their educational goals. Academic performance is commonly measured by examinations or continuous assessment but there is no general agreement on how it is best tested or which aspects are more important. Academic performance seems to increase when time management skills are well-handled. Time management is a skill that perhaps impacts the students academic performance. Prioritization of tasks may make studying and schoolwork less overwhelming and more enjoyable. Academic stress occurs when students feel the pressure of cramming for exams, rushing through homework and getting minimal sleep because of disorganizations and worry. Effective time management techniques should not only be applied to the students' academic life but to their overall schedule to achieve success and peace of mind. 
Grades in higher institutions often depend on the completion of a range of tasks, including those with various deadlines, lengths and priorities. This multiple tasks, and then grades are determined by the quality of efforts put in. Thus, academic performance would be expected to be influenced by time management skills. Therefore, as increasing demands are placed on students, students' ability to manage time becomes an essential component for academic success.

Proper time management becomes important in education especially at higher levels because it suggests among other factors, how fast manpower can be available in the life of a nation. King (2002) identifies various external forces confronting time and outlines them to be combination of factors: challenge to one's ability or expertise, which imposes an unwelcome demand on time, abilities and emotional reserves. The researcher however feels it may be an overstatement that forces from outside have the power to enforce the demand of time. It is also important to note that time wasting inhibits getting a job done. Achunie (1998) pinpoints time wasters in school system as numerous factors that influence time management practices. The following are noted: events that just come up. Various events that are not planned may come up within the school system. Events like lecturers' strike, students' unrest, sudden accidents, fire outbreak and many other emergencies can interfere with students' daily schedule. In reality, the researcher support this view of unforeseen issues can take days, weeks, month or a whole semester to resolve like the recent strike action by ASUU nation wide that started in June 2013 and still indefinite. Austin, Dwyer and Freebody (2003) speak about lack of time management among students who experience frustration in trying to get themselves to start their works. Knaus (1996) shares this view by saying that students may be overwhelmed by the task to the extent of putting off academic assignments till later date, or spending a great deal of time with friends and on social activities, or worrying about upcoming examination, class project and papers rather than completing them. To the researcher, unforeseen issue can come up and spending the time allocated for an event on another will be realistic. It is also gives room for uneasiness and tension which result in messing up to the planned programme. However, there are many activities that unnecessarily consume time and its utilization. These makes time to be wasted or fly away without achieving much. Although, Yager (1999) is not comfortable with the phrase "wasting time”, to him, time cannot be wasted but mismanaged. Time wasting is misconception, he says. The Researcher however feels that whatever is mismanaged is wasted. King (2002) says, in the process of doing an important task, one can suddenly begin to find many unrelated things that urgently need attention. For example re-reading old books, cleaning out rooms, calling people you have not spoken to in month-all as one waits for the perfect time to begin the work at hand. Knaus (1996) supports this view by saying that when one sits day-dreaming, staring into space, looking at pictures of one's boyfriend/girlfriend instead of doing the task, time is wasting. Sometimes the environment is noisy and sometimes one sits/lay on the bed to study or do assignments. The Researcher feels that this may be common to students especially when there is much to cover and they are looking for the best time to read. It is also common among students because of the ways school hostels are arranged where more than two students will be in a room, studying may be difficult especially for those who enjoy midnight reading who will not like to disturb others. It may be possible when both of them are 
interested in studying at night. With many distractions around, attention can be diverted to something else. Quek (2001) in his reflection on time management proposes that procrastination and prioritorization are probably the most common time management problems among students. To him, some students battle with procrastination due to lack of time management, especially when they cannot meet the deadline.

However, it seems everybody procrastinates. Procrastination plagues people of all occupations and that we all procrastinate at one time or another in our life. Hence, procrastination is everybody's problem which implies that everybody delay in one way or the other. Though, the levels of procrastination vary from one person to another. The truth is that everybody has a way of day-dreaming and a way of not respecting time; but some do it to the extent of abandoning urgent task.

The researcher observes that that students are directly involved in academic procrastination since at the beginning of a semester, one in five students miss the first class, some sign up early but never show, while others attend sporadically. Not all students are conscious that academic procrastination raises students' anxiety and sinks their self esteem in view of the fact that time wasted can hardly be regained. Also, students don't feel there is the need to prioritize their works in order of importance.

Upon this backdrop, the researcher delved into the Time management and students academic performance in higher institutions, Nigeria: A Case study of Ekiti State.

\subsection{Statement of the Problem}

Some observed problems in certain areas in the academic activities of students may owe their causes largely to time management. This is when the students do not manage their time properly. They may not come or may delay in coming to school. There may be delay in planning for academic activities postponement of time to do assignment and reading for tests and examination. They may be facing interruptions during the lectures hours like receiving lengthy calls, pinging, social networks and mingle with friends. This has some influences on some areas of academic activities especially in the academic performance.

Consequent upon these, the study will investigate the effects of time management on students' academic performance.

\subsection{Purpose of the Study}

The purpose of this study is to find out the influence of time management on students academic performance using the variables such as planning, procrastination, prioritization to determine how they made use of their time.

\subsection{Research Questions}

(i) Is there any relationship between time management and academic performance of students in higher institutions?

(ii) Is there any relationship between procrastination and students academic performance? 
(iii) Is there any signficance relationship between prioritization and students academic performance in higher institution?.

(iv) Is there any significance difference in the impact of time management on student's academic performance on the basis of gender in higher institutions?

\subsection{Research Hypothesis}

(i) There is no significant relationship between time management and student academic performance in higher institutions.

(ii) There is no significant relationship between procrastination and students academic performance in higher institutions.

(iii) There is no significant relationship between prioritorization and students academic performance.

(iv) There is no significant difference in the impact of time management on students academic performance on the basis of their gender.

\section{Methods}

\subsection{Research Method}

The study is a descriptive research of survey type.

\subsection{Population}

The target population for this study was the entire students of Ekiti State tertiary institutions.

\subsection{Sample and Sampling Techniques}

The sample of this study was 200 respondents which comprised 100 students from Ekiti State University and 100 students from Federal Polytechnic, Ado-Ekiti. Purposive and stratified sampling techniques were used to select 100 male students and 100 female students from 300 Level of the two institutions.

\subsection{Research Instruments}

Two instruments were used to carry out the investigation. A structured questionnaire developed by the researcher, administered on the students of the two higher institutions under study in order to collect information on how they manage their time for their academic activities. The instrument tagged Time Management and Students Academic Performance (TMSAP) has two sections (A and B). Section A of the questionnaire was designed to collect information on personal Data of the respondents while section B of the questionnaire was meant to collect information on how students manage their time. An inventory was used to collect the results. See appendices $1 \& 11$.

\subsection{Validity of the Instrument}

The instrument was validated using face and content validity. The face validity was done by looking at the layout and the structure of the instrument while the content validity was 
determined by experts in the field of time management who examined each item of the instrument and matching them with the research questions in order to determine whether the instrument actually measured what is suppose to measure.

\subsection{Reliability of the Instrument}

The method of test-retest was used to measure the reliability of the instrument. The results of the two consecutive tests were then correlated by using Pearson Product Moment co-efficient of correlation. The reliability coefficient of 0.74 was obtained. Reliability was not conducted for the inventory because the data collected through the inventory already existed in the tertiary institutions and could not be manipulated. The second semester CGPA of the 300 level students were collected based on the classes of grade. 5 was attached to first class, 4 attached to second class upper division, 3 attached to second class lower division, 2 attached to third class and 1 to pass. See appendix 1.

\subsection{Administration of Instrument}

The researcher and research assistants visited the selected schools and administered the questionnaire (TMSAP). The researcher was able to retrieve 167 questionnaires. 156 out of the 167 questionnaires that were properly filled were subjected to analysis. The senate approved results of the respondents were collected from their departments. The 300 level second semester senate approved results of the respondents were collected from their departments.

\section{Data Analysis}

The data collected were analyzed using inferential statistics. Hypotheses were tested at 0.05 level of significance.

HO $\mathbf{I}_{\text {I: }}$ There is no significant relationship between the time management and students academic performance in higher institutions.

Table 1. Relationship between students’ time management and academic performance

\begin{tabular}{lllll}
\hline Variables & N & r-cal & r-table & Decision \\
\hline Time management & 156 & 0.798 & 0.195 & HO $_{1}$ rejected \\
Academic performance & 156 & & & \\
\hline
\end{tabular}

$\mathrm{P}>0.05$.

Table 1 shows that calculated r-value is 0.798 and the table r-value is 0.195 at 0.05 level of significance. This reflects that r-cal is greater than r-table. Then the null hypothesis is rejected and the alternative hypothesis upholds that there is significant relationship between students' time management and their academic performance in higher institutions.

$\mathbf{H O}_{2}$ : There is no significant relationship between the student's social activities and their academic performance in higher institutions. 
Table 2. Relationship between the time students spend on social activities and their academic performance

\begin{tabular}{lllll}
\hline Variables & $\mathbf{N}$ & r-cal & r-table & Decision \\
\hline Time management & 156 & 0.574 & 0.195 & $\mathrm{HO}_{2}$ rejected \\
Academic performance & 156 & & & \\
\hline $\mathrm{P}>0.05$. & & & &
\end{tabular}

Table 2 reveals that $\mathrm{r}$-cal is 0.574 and $\mathrm{r}$-table is 0.195 . It implies that $\mathrm{r}$-cal is greater than r-table at 0.05 significant level. The null hypothesis is rejected. Therefore, there is significant relationship between the time students spend on social activities and their academic performance in higher institutions.

$\mathbf{H O}_{3}$ : There is no significant relationship between procrastination and students academic performance in higher institution.

Table 3. Relationship between procrastination and students academic performance

\begin{tabular}{lllll}
\hline Variables & $\mathbf{N}$ & r-cal & r-table & Decision \\
\hline Procrastination & 156 & 0.638 & 0.195 & $\mathrm{HO}_{3}$ rejected \\
Academic performance & 156 & & & \\
\hline
\end{tabular}

$\mathrm{P}>0.05$.

Table 3shows that r-cal is 0.638 and r-table is 0.195 . It implies that $\mathrm{r}$-cal is greater than $\mathrm{r}$-table at 0.05 significant level. The null hypothesis is rejected. Therefore, there is significant relationship between procrastination and students academic performance.

$\mathbf{H O}_{4}$ : There is no significant relationship between prioritization and students academic performance in higher institutions.

Table 4. Relationship between prioritization and students academic performance

\begin{tabular}{lllll}
\hline Variables & $\mathbf{N}$ & r-cal & r-table & Decision \\
\hline Prioritization & 156 & 0.424 & 0.195 & $\mathrm{HO}_{4}$ rejected \\
Academic performance & 156 & & & \\
\hline $\mathrm{P}>0.05$. & & & &
\end{tabular}

Table 4 reveals that $\mathrm{r}$-cal is 0.424 and $\mathrm{r}$-table is 0.195 . It shows that $\mathrm{r}$-cal is greater than r-table at 0.05 level of significance. The null hypothesis is rejected. Therefore, there is a significant relationship between prioritization and students academic performance in higher institutions.

$\mathbf{H O}_{5}$ : There is no significant differences in the impact of time management on students academic performance on the basis of their gender. 
Table 5. Relationship between time management and students academic performance on the basis of gender

\begin{tabular}{llllllll}
\hline Sex & $\mathbf{N}$ & $\mathbf{X}$ & SD & DF & t-cal & t-table & Decision \\
\hline Male & 87 & 28 & 5.29 & & 1.54 & 1.96 & $\mathrm{H} 0_{5}$ \\
Female & 69 & 21 & 4.58 & 198 & & & Accepted \\
\hline
\end{tabular}

$\mathrm{P}<0.05$.

Table 5 reveals that $\mathrm{t}$-cal is 1.54 and t-table is 1.96 . It implies that t-cal is lesser than t-table at 0.05 level of significance. The null hypothesis is accepted. Therefore, there is no significant difference in the impact of time management on students academic performance on the basis of their gender.

\section{Discussion}

The study showed that there was significant relationship between time management and students academic performance. It gives the impression that students need the proper use of time before they can be effective in their various assignments. All the activities being performed by students are done within the time hence time management cannot be separated from academic achievement. Akomolafe (2005) advocated proper usage of time by principals so as to be effective on the job and spent less time on receiving telephone calls instead should engage their secretaries to screen their telephone calls. Implicit in this is that the issue of proper time management is not peculiar to the students alone but to the administrators that are to be examples to them. Hence, this study has established that students should spend their time wisely and spend it judiciously for improved academic performance. The study also showed that there was a relationship between the time spent on social activities and their academic performance. This means that the students need to regulate or reduce the amount of time spent on activities such as attending dinners and parties, chatting, phoning and pinging as these have serious negative impact on their academic performance. The more time students spend on social activities the more their educational activities are affected. Thus, it affects the fulfillment and achievement of educational goals of the students.

The study further showed that there was significant relationship between procrastination and academic performance. This implies that students must be wary of regular postponement of actions or events or assignments that can make their study difficult since this can affect their performance. The result may be due to the fact that some students do not meet the deadline in performing some academic activities because of the feelings that time is always available for their use, not keeping in mind some issues that can suddenly come up. Adebayo and Omojola (2012) reinstated that the administrators of higher institutions postponed assignments most often and this had effect on their effectiveness. Perhaps, this is transferred to the students' altitude to improper time management. Hence, this study came out that students should minimize procrastination.

The study also revealed that there was a significant relationship between prioritization and academic performance. The study came out with the indication that lack of setting regular or 
daily goals do affect academic activities. What may be responsible for the findings is that goals are not arranged or performed according to order of importance and urgency by the students. The study of Agarwal (2008), Bradley and Mcrae (2007) opined that students need to be self disciplined in planning their time to improve their performances.

The study further revealed that there is no significant difference in the impact of time management on student's academic performance on the basis of their gender. This means that the male students as well as their female counterpart use their time in similar ways. This is in agreement with Omolola (2010) study which concluded that both male and female undergraduate are affected by time management.

\section{Conclusion}

Based on the findings of this study, the following conclusions are drawn:

Lack of proper time management on the part of the students have some impacts on certain academic activities especially in the area of resumption for the new semester or session, registration of courses, attending lectures, doing the assignment, reading for test and preparation for examination to time. These are as a result of procrastination and not paying attention to issues like planning and prioritization.

\section{Recommendations}

Based on the findings of this study, the following recommendations were made:

Students especially those in the higher institutions should use the findings of this work to improve on their time management. They have to be conscious of time in performing their academic activities so that the level of their academic performance can be high.

Since procrastination among all the variables has much impact on academic performance according to the findings, students should strive hard to complete their assignments as well as other academic activities on time so as to avoid not meeting deadlines.

Also, procrastination is a strong time management variable among the students efforts should be geared towards organizing seminars by the social organization on how to address this cankerworm that has eaten deep into the lives of our students.

\section{References}

Adebayo, F. A., \& Omojola, I. (2012). Influence of Time Management on Administrative Effectiveness in higher institutions in Ekiti State, Nigeria. International Journal of Educational Research and Technology, 3(1), 52-60.

Achunine, R. N., \& Irondi, E. O. (1998). Management Administration of secondary education in Nigeria. Lagos: Totan Publishers Limited.

Akomolafe, C. O. (2005). Principals Time Management abilities in secondary schools in Nigeria. Nigerian Journal of Educational Administration and Planning, 5(1), 58-67.

Agarwal, A. (2008). Self discipline for student-influences on time management. Retrieved 
August 19, 2012, from http://www.ezinarticles.com

Austin, H., Dwyer, B., \& Freebody, P. (2003). Schooling the child. London: Rutledge Falmer.

Gerard, M. (2002). Negative influences of time management. Retrieved from www.eskishore. Com/tiometips52.asp

King, J. M. C. (2002). The procrastination syndrome, signs, symptoms, and treatment cultural studies and analysis. Philadelphia: stoke publisher.

Knaus, W. J. (1996). Procrastination. New York: Institute for Rational Therapy.

Maya, M. (2008). The positive influences of time management. Retrieved from www.Selfgrwoth.com

Omolola A. D. (2010): Time management among the Nigerian undergraduates - A case study of University of Ado Ekiti, Nigeria. Unpublished Undergraduate Project.

Quek, T. (2001). Procrastination. C.E.O Dexterity soft ware.

Wiegers, K. E (2010). Prioritization Soft ware Requirement (2nd ed.). Redmond, W.A: Microsoft Press.

Yager, J. (1999). Creative time management for the new millennium. Benin city: self-improvement publishing.

\section{APPENDIX 1}

CGPA OF THE TWO TERTIARY INSTITUTIONS 2012/2013

\begin{tabular}{|l|l|l|l|l|l|}
\hline Institution & $\begin{array}{l}\text { Total number } \\
\text { of First class } \\
(5)\end{array}$ & $\begin{array}{l}\text { Total number } \\
\text { of Second } \\
\text { class upper } \\
\text { division(4) }\end{array}$ & $\begin{array}{l}\text { Total number } \\
\text { of Second } \\
\text { class lower } \\
\text { division(3) }\end{array}$ & $\begin{array}{l}\text { Total number } \\
\text { of Third class } \\
\text { (2) }\end{array}$ & $\begin{array}{l}\text { Total number } \\
\text { of Pass(1) }\end{array}$ \\
\hline A & & & & & \\
\hline B & & & & & \\
\hline
\end{tabular}


APPENDIX 1I

\section{TIME MANAGEMENT QUESTIONNAIRE}

BIO - DATA

Name of institution:

Department:

Matriculation Number:

Sex: $\quad$ Male

Female

INSTRUCTIONS: Tick as appropriate

\begin{tabular}{|c|c|c|c|}
\hline $\mathrm{S} / \mathrm{N}$ & ITEMS & Agree & Disagree \\
\hline & PRIORITISATION & & \\
\hline 1 & $\begin{array}{l}\text { I always work out strategies for } \\
\text { carrying out my daily duties }\end{array}$ & & \\
\hline 2 , & $\begin{array}{l}\text { I write the task to be performed down } \\
\text { in order of priority }\end{array}$ & & \\
\hline 3 & Iperformed task in order of priority & & \\
\hline 4. & $\begin{array}{l}\text { I assess the accomplishment of } \\
\text { priorities daily }\end{array}$ & & \\
\hline \multirow[t]{2}{*}{5.} & I allocate time for daily activities & & \\
\hline & PROCRASTISATION & & \\
\hline 6. & I see time as always available & & \\
\hline 7. & I postpone duties & & \\
\hline 8. & $\begin{array}{l}\text { I am not in a hurry to perform my } \\
\text { duties }\end{array}$ & & \\
\hline 9. & I like extension of work & & \\
\hline \multirow[t]{3}{*}{10} & I love leisure. & & \\
\hline & & Most often & Often \\
\hline & SOCIAL ACTIVITIE & & \\
\hline 11. & I like phoning & & \\
\hline 12. & I spend much time on pinking & & \\
\hline 13. & Browsing is part of me & & \\
\hline 14. & Networking is my hobby & & \\
\hline 15. & I attend lectures regularly & & \\
\hline 16. & I read & & \\
\hline 17. & I made use of the Library. & & \\
\hline \multirow[t]{2}{*}{18.} & I do my Course assignment. & & \\
\hline & I get involve in: & & \\
\hline 19. & Dating & & \\
\hline 20. & Parties & & \\
\hline 21. & Religious activities & & \\
\hline 22. & Physical activities & & \\
\hline
\end{tabular}




\section{Copyright Disclaimer}

Copyright reserved by the authors.

This article is an open-access article distributed under the terms and conditions of the Creative Commons Attribution license (http://creativecommons.org/licenses/by/3.0/). 